\title{
A Phytoplasma Related to 'Candidatus Phytoplasma asteris' Detected in Citrus Showing Huanglongbing (Yellow Shoot Disease) Symptoms in Guangdong, P. R. China
}

\author{
J. Chen, X. Pu, X. Deng, S. Liu, H. Li, and E. Civerolo
}

First and sixth authors: U.S. Department of Agriculture-Agricultural Research Service (USDA-ARS), Parlier, CA; second, third, and fifth authors: Citrus Huanglongbing Research Laboratory, Department of Plant Pathology; and fourth author: Department of Soil Science, South China Agricultural University, Guangzhou, Guangdong, P. R. China.

Current address of first author: San Joaquin Valley Agricultural Sciences Center, USDA-ARS, Parlier, CA 93648.

Current address of third author: Citrus Huanglongbing Research Laboratory, Department of Plant Pathology, South China Agricultural

University, Guangzhou, Guangdong 510642, P. R. China.

Accepted for publication 17 October 2008.

\begin{abstract}
Chen, J., Pu, X., Deng, X., Liu, S., Li, H., and Civerolo, E. 2009. A phytoplasma related to 'Candidatus Phytoplasma asteris' detected in citrus showing huanglongbing (yellow shoot disease) symptoms in Guangdong, P. R. China. Phytopathology 99:236-242.

Citrus huanglongbing (HLB) or yellow shoot disease (i.e., greening disease) is highly destructive to citrus production worldwide. Understanding the etiology of HLB is critical for managing the disease. HLB is currently associated with infection by 'Candidatus Liberibacter spp.' around the world, including China. However, Koch's postulates have not been fulfilled. In addition, other plant pathogens also may be involved in HLB. In a survey performed in Guangdong Province, P. R. China in 2006 and 2007, 141 citrus samples showing typical symptoms of HLB from 11 different cities were collected. Polymerase chain reaction (PCR) using phytoplasma-specific primer sets fU5/rU3 nested with primer set P1/P7 identified 110 (78.0\%) positive samples. A 1,785-bp amplicon was obtained with primer set P1/P7. Analysis showed a $100 \%$ identity of this sequence in the region of $16 \mathrm{~S}$ rDNA and 16S-23S rRNA intergenic tran-

scribed spacer to three strains of 'Candidatus Phytoplasma asteris' (onion yellows [Japan], aster yellows 'watercress' [Hawaii], and valeriana yellows [Lithuania]). Of the 141 samples, $89(63.1 \%)$ samples were positive for ' $\mathrm{Ca}$. Liberibacter asiaticus'. When mixed infection was considered, 69 (48.9\%) samples were positive for both ' $\mathrm{Ca}$. P. asteris' and ' $\mathrm{Ca}$. L. asiaticus'. Transmission electron microscopy (TEM) showed low titers of both walled and wall-less bodies in the phloem sieve tubes of HLB citrus. When transmission from symptomatic citrus to periwinkle (Catharanthus roseus) via dodder (Cuscuta campestris) was conducted, both phytoplasma and ' $\mathrm{Ca}$. L. asiaticus' were detected from the affected periwinkle. In addition to yellowing/mottling, the infected periwinkle showed symptoms of virescence and phyllody which are commonly associated with phytoplasmal diseases. TEM analysis of affected periwinkle revealed pleomorphic and wall-less organisms, characteristic of phytoplasmas, filling some phloem sieve tubes. In contrast, walled bacteria were at low titer. This study showed that in addition to ' $\mathrm{Ca}$. L. asiaticus', a phytoplasma related to ' $\mathrm{Ca}$. P. asteris' could also be detected in citrus showing HLB symptoms in Guangdong.
\end{abstract}

Huanglongbing (HLB) or yellow shoot disease (i.e., greening disease) is one of the most destructive diseases in citrus production around the world (3). In China, HLB was noted probably in the late 1880s in Guangdong Province (26). The infectious nature of HLB was suggested in 1943 (5) and experimentally demonstrated in 1956 (27). In searching for the etiological agent, Lin (27) suggested the involvement of viruses. Rickettsia-like organisms (RLOs) or bacteria-like organisms (BLOs) and mycoplasma-like organisms (MLOs, now named phytoplasmas) were observed in infected tissue $(6,21)$. Jagoueix et al. (19) reported that HLB was associated with an alpha-proteobacterium, and suggested the trivial name Liberobacter, which was later changed to 'Candidatus Liberibacter' (15). Despite the lack of fulfillment of Koch's postulates, ' $\mathrm{Ca}$. Liberibacter' has been considered as the most probable etiological agent of HLB. Currently, three 'Candidatus' species of Liberibacter, 'Ca. L. asiaticus', 'Ca. L. africanus', and ' $C a$. L. americanus', have been proposed $(7,19,31,36)$.

Corresponding authors: J. Chen; E-mail address: Jianchi.chen@fresno.ars.usda.gov X. Deng; E-mail address: xldeng@ scau.edu.cn

doi:10.1094/PHYTO-99-3-0236

This article is in the public domain and not copyrightable. It may be freely reprinted with customary crediting of the source. The American Phytopathological Society, 2009
HLB is currently diagnosed by symptomatology and confirmed by polymerase chain reaction (PCR) detection of ' $\mathrm{Ca}$. Liberibacter'. In China, only ' $\mathrm{Ca}$. L. asiaticus' has been associated with HLB so far. The sequence of OI1 was used as a signature to define ' $C a$. L. asiaticus' $(19,36)$. Primers OI1 and OI2c are the standard primer set for detection of ' $C a$. L. asiaticus' $(19,20)$. However, we observed that primer set OI1/OI2c may not always yield a positive PCR from citrus samples with typical HLB symptoms (X. Deng, unpublished data). The most common explanation is that the titer of ' $\mathrm{Ca}$. L. asiaticus' cells in the tested plant tissues is below the PCR detection limit. Another possibility is that disease symptoms are due to other causes (e.g., mineral deficiency). However, it is also possible that pathogens other than ' $\mathrm{Ca}$. L. asiaticus' may be involved in the etiology of HLB.

To facilitate studying non-culturable pathogens of this woody host, Garnier and Bove (14) transmitted HLB-associated bacteria from citrus collected in India and South Africa to periwinkle (Catharanthus roseus [L.] G. Don.) via dodder (Cuscuta campestris Yunck) and observed a high titer of walled bacteria in the infected periwinkle tissues by transmission electron microscopy (TEM). Subsequently, Tang and Faan (35) in Guangdong successfully performed a reciprocal transmission of HLB-associated bacteria between citrus and periwinkle via dodder. In addition to the yellowing and mottling, they reported that infected periwinkle also showed symptoms of virescence and phyllody and noted the 
presence of pleomorphic organisms in some infected periwinkle and citrus tissues. In this study, our objectives were to (i) verify the occurrence of a phytoplasma in HLB-affected citrus and (ii) characterize the phytoplasma by nucleotide sequence analyses, TEM, and symptomatology in periwinkle after transmission from HLB affected citrus.

\section{MATERIALS AND METHODS}

Plant material. Two citrus HLB surveys were carried out in Guangdong (Table 1). In the first survey, 71 HLB samples were collected from six cities in October, 2006. The plant species surveyed included mandarin (Citrus reticulata Blanco), sweet orange $(C$. sinensis [L.] Osbeck) and pummelo ( $C$. maxima [Burn.] Merrill) (33). A second survey was performed in September to October 2007 with 70 samples of mandarin, sweet orange, and pummelo collected from five cities. Leaf samples were collected based on typical HLB leaf yellowing/mottling symptoms (Fig. 1) and shipped to the Huanglongbing Research Laboratory at the South China Agricultural University in Guangzhou. Upon arrival, the samples were stored at $4{ }^{\circ} \mathrm{C}$ and processed within $48 \mathrm{~h}$. Leaves from mandarin trees known to be affected with HLB and free of HLB maintained in the screenhouse on the campus of South China Agricultural University (SCAU) were

TABLE 1. Poloymerase chain reaction (PCR) detection of 'Candidatus Liberibacter asiaticus' and 'Ca. Phytoplasma asteris' in leaf tissue samples collected during two citrus Huanglongbing surveys in Guangdong Province, PRC, in 2006 and 2007

\begin{tabular}{|c|c|c|c|c|c|c|c|c|c|}
\hline & \multirow[b]{2}{*}{ City } & \multirow[b]{2}{*}{ No. of orchards } & \multirow[b]{2}{*}{ No. of plants sampled ${ }^{\mathrm{a}}$} & \multicolumn{6}{|c|}{ PCR result ${ }^{\mathrm{b}}$} \\
\hline & & & & CLA+ & $\mathrm{CPA}+$ & $\begin{array}{l}\text { CLA + } \\
\text { CPA + }\end{array}$ & $\begin{array}{l}\text { CLA - } \\
\text { CPA - }\end{array}$ & $\begin{array}{l}\mathrm{CLA}+ \\
\mathrm{CPA}-\end{array}$ & $\begin{array}{l}\text { CLA - } \\
\text { CPA + }\end{array}$ \\
\hline \multicolumn{10}{|l|}{2006 Survey } \\
\hline 2 & Gaoyao & 5 & $16(0,0,16)$ & 14 & 12 & 11 & 1 & 3 & 1 \\
\hline 3 & Gaoming & 2 & $3(1,1,1)$ & 2 & 3 & 2 & 0 & 0 & 1 \\
\hline 4 & Lechang & 5 & $19(0,2,17)$ & 11 & 16 & 10 & 2 & 1 & 6 \\
\hline$\%$ & & & & 70.4 & 78.9 & 57.7 & 8.5 & 12.7 & 21.1 \\
\hline \multicolumn{10}{|l|}{2007 Survey } \\
\hline 1 & Sihui & 1 & $10(0,0,10)$ & 4 & 9 & 3 & 0 & 1 & 6 \\
\hline 2 & Changgansan & 1 & $20(5,6,9)$ & 11 & 15 & 7 & 1 & 4 & 8 \\
\hline 3 & Luoding & 1 & $11(0,0,11)$ & 9 & 8 & 7 & 1 & 2 & 1 \\
\hline 4 & Huizhou & 2 & $25(15,0,10)$ & 12 & 18 & 8 & 3 & 4 & 10 \\
\hline$\%$ & & & & 63.1 & 78.0 & 48.9 & 7.8 & 14.2 & 29.1 \\
\hline
\end{tabular}

${ }^{a}$ Numbers in parentheses are sweet orange (Citrus sinensis [L.] Osbeck), pummelo (Citrus maxima [Burm.] Merrill), and mandarin (Citrus reticulata Blanco), respectively.

${ }^{\mathrm{b}}$ CLA = 'Candidatus Liberibacter asiaticus'. The bacterium was identified by nested PCR using primer sets fD1/fD2 (1st round) and OI1/OI2c (2nd round) or by real-time PCR with primer set HLBas/HLBr and TaqMan probe HLNp as detailed in Table 1. CPA = 'Candidatus Phytoplasma asteris'. The bacterium was determined by nested PCR using primer sets P1/P7 (1st round) and fU5/fU3 (2nd round) as listed in Table 2.

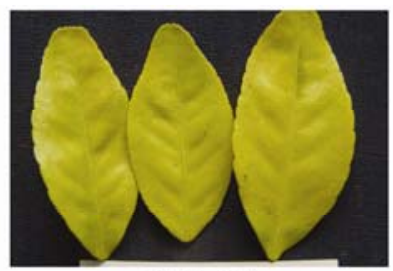

GY-10

'Ca. P. asteri'

'Ca. L. asiaticus'

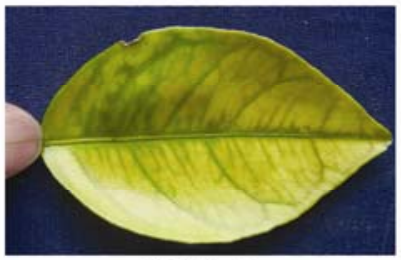

WY-3

'Ca. P. asteri'

'Ca. L. asiaticus'

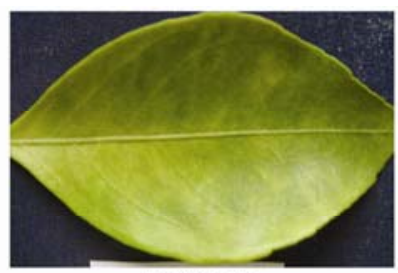

HS7-3

$+$

$+$

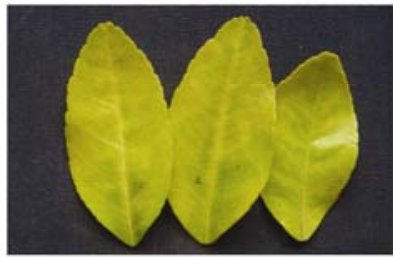

GY-13

$+$

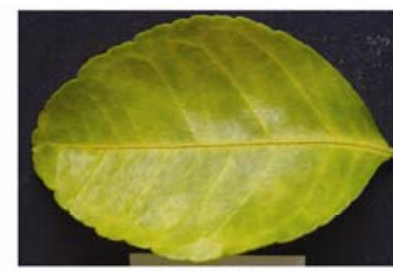

HS2-3

-

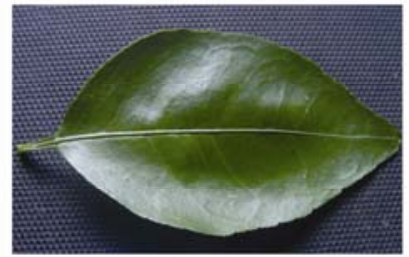

CK

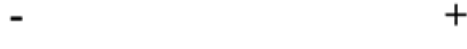

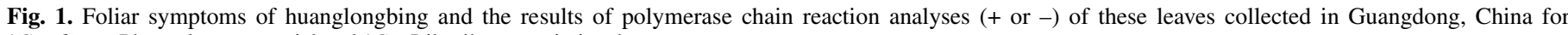
'Candiatus Phytoplasma asteris' and ' $\mathrm{Ca}$. Liberibacter asiaticus'. 
used as sources of DNA for positive and negative controls, respectively.

Experiments with periwinkle were performed in an insect-proof screenhouse on the campus of South China Agricultural University. Each of four $15-\mathrm{cm}$ tall periwinkle plants, grown from seeds, was grafted with one bud from an HLB-affected periwinkle plant previously infected via dodder transmission from an HLBaffected mandarin tree in Sihui City of Guangdong Province and maintained in an insect-proof screenhouse. Symptom development in each grafted periwinkle was recorded weekly. Symptomatic leaves were collected for DNA extraction and bacterial examination. Nongrafted periwinkle plants were used as controls.

DNA extraction. Midribs of plant leaves were excised with a sterile razor blade. DNA was extracted using the cetyltrimethylammonium bromide (CTAB) method as previously described $(9,30)$. Briefly, $0.5 \mathrm{~g}$ of midribs was cut into small pieces with sterilized scissors, frozen with liquid nitrogen then ground into powder with a mortar and pestle. Two milliliters of a $2 \%$ CTAB buffer were added, the mixture was transferred into a $1.5-\mathrm{ml}$ microcentrifuge tube and incubated in a water bath at $65^{\circ} \mathrm{C}$ for 30 min with occasional agitation. After extraction with a phenol/ chloroform/iso-amyl alcohol solution (24:24:1), DNA was precipitated by the addition of $1 / 10$ volume of $3 \mathrm{M}$ sodium acetate ( $\mathrm{pH}$ 5.2) and two volumes of alcohol and was collected by centrifugation. The pellets were dissolved in $100 \mu \mathrm{l}$ of Tris-EDTA buffer $(10 \mathrm{mM}$ Tris- $\mathrm{HCl}, 1 \mathrm{mM}$ EDTA, $\mathrm{pH}$ 8.0) with $0.5 \mu \mathrm{l}$ of RNaseA $(10 \mathrm{mg} / \mathrm{ml})$ and incubated in a water bath at $37^{\circ} \mathrm{C}$ for 30 min. DNA was stored at $-20^{\circ} \mathrm{C}$ for later use in Guangdong or in California.

PCR. Primer sets used in this study are listed in Table 2. Samples from the first survey were tested in the USDA-ARS laboratory at Parlier, CA (US Lab). Phytoplasma were detected by nested PCR. Primer set P1/P7 $(8,34)$ was used for the first round (10 cycles) and primer set fU5/rU3 (29) was used for the second round (30 cycles) following a previously described procedure (13). PCR reactions $(25-\mu \mathrm{l})$ were carried out using the TaKaRa taqTM (Hot Start Version) kit (Takara Bio Inc., Seta 3-4-1, Otsu, Shiga, 520-2193, Japan). The reaction mixture contained: $2.5 \mu \mathrm{l}$ of $10 \times$ DNA polymerase buffer, $2.5 \mu \mathrm{l}$ of dNTPs $(2.5 \mathrm{mM}$ of each $\mathrm{dNTP}), 0.5 \mu \mathrm{l}$ each of the forward and reverse primers $(10 \mu \mathrm{M})$, $1 \mu \mathrm{l}$ of sample DNA, $0.2 \mu \mathrm{l}$ of Taq DNA polymerase $(5 \mathrm{U} / \mu \mathrm{l})$ and $18.3 \mu \mathrm{l}$ of $\mathrm{H}_{2} \mathrm{O}$. Amplification was conducted in an MJ Research Tatrad DNA Engine 2 with an initial denaturation at $96^{\circ} \mathrm{C}$ for $10 \mathrm{~min}$, followed by either 10 or 30 cycles of denaturation at $96^{\circ} \mathrm{C}$ for $30 \mathrm{~s}$, annealing at $55^{\circ} \mathrm{C}$ for $30 \mathrm{~s}$, and extension at $72^{\circ} \mathrm{C}$ for $30 \mathrm{~s}$. ' $\mathrm{Ca}$. L. asiaticus' was detected by the same nested PCR protocol but using primer set fD1/rD1 (19) in the first round and primer set OI1/OI2c (19) in the second round. Amplified products were evaluated by electrophoresis in $1.5 \%$ agarose gels and visualized by staining with ethidium bromide.

Samples from the second survey were tested in the Citrus Huanglongbing Laboratory in South China Agricultural University in Guangzhou, P. R. China (China Lab). Nested PCR was used for phytoplasma detection. PCR was carried out in a final volume of $25 \mu \mathrm{l}$ with a Perkin Elmer GeneAmp 2400 PCR System. The reaction mixture contained: $2.5 \mu \mathrm{l}$ of $10 \times$ DNA polymerase buffer, $2 \mu \mathrm{l}$ of dNTPs ( $2.5 \mathrm{mM}$ of each dNTP), $1 \mu \mathrm{l}$ each of the forward and reverse primers $(5 \mu \mathrm{M}), 1 \mu \mathrm{l}$ of sample DNA, $0.2 \mu$ of Taq DNA polymerase ( $5 \mathrm{U} / \mu \mathrm{l}$, Shanghai Shenergy Biocolor BioScience and Technology Company, PRC), and $18.3 \mu \mathrm{l}$ of double distilled $\mathrm{H}_{2} \mathrm{O}$. DNA amplification by PCR was performed as follows: reactions were preheated at $94^{\circ} \mathrm{C}$ for $5 \mathrm{~min}$, followed by 10 cycles (first round) or 35 cycles (second round) of denaturation at $94^{\circ} \mathrm{C}$ for $1 \mathrm{~min}$, annealing at $56^{\circ} \mathrm{C}$ for $1 \mathrm{~min}$ and extension at $72^{\circ} \mathrm{C}$ for $2 \mathrm{~min}$, with a final extension at $72^{\circ} \mathrm{C}$ for $10 \mathrm{~min}$. Amplified products were evaluated by electrophoresis in $1 \%$ agarose gels after staining with ethidium bromide.

' $\mathrm{Ca}$. L. asiaticus' was detected by TaqMan real-time PCR following the procedure of $\mathrm{Li}$ et al. (25). Briefly, the reaction mixture $(20 \mu \mathrm{l})$ consisted of PCR master mix, $10 \mu \mathrm{mol}$ of primers HLBas and HLBr, $5 \mu$ mol TaqMan probe (HLBp) (Table 1), and $1 \mu \mathrm{l}$ of the extracted sample DNA. A cloned plasmid containing a fragment of $16 \mathrm{~S}$ rDNA of ' $\mathrm{Ca}$. L. asiaticus' was used as positive control. Sterilized water was used as negative control, along with DNA from healthy citrus trees as mentioned previously. Amplification, detection, and data analysis were performed with an ABI PRISM 7000 Sequence Detection System (Applied Biosystems, Foster City, CA). The thermal profile consisted of an initial activation step at $95^{\circ} \mathrm{C}$ for $5 \mathrm{~min}$ followed by 40 cycles at $95^{\circ} \mathrm{C}$ for $30 \mathrm{~s}$ and $58^{\circ} \mathrm{C}$ for $45 \mathrm{~s}$.

DNA sequence analyses. Eighteen selected PCR amplicons from symptomatic leaf samples of mandarin, sweet orange, pummello, and periwinkle obtained with primer set fU5/rU3 were sequenced directly with a 3130xl Genetic Analyzer (Applied Biosystem, Foster City, CA). A phytoplasma strain from a mandarin tree in Wengyuan City and a strain from periwinkle were selected for standard PCR amplification with primer set P1/P7 for 30 cycles. P1/P7 flanks the region of 16S rDNA and 16S-23S rRNA intergenic transcribed spacer (ITS). DNA amplicons $(\approx 1,800 \mathrm{bp})$ were cloned into pGEM-T Easy vector and sequenced. DNA fragments were sequenced three times from both directions to check for accuracy. DNA sequences were compared to the current GenBank database using the BLASTn network service available in the National Center for Biotechnology Information. Multiple sequence alignments were performed using the 'Query-anchored with identities' option within the BLASTn tool or using CLUSTAL W (38).

TEM. Bacteria in the sieve tubes of phloem of periwinkle and mandarin showing HLB symptoms were examined by TEM following the protocol of Tang and Faan (35). Briefly, midribs of periwinkle and citrus leaves were collected and cut to $1 \mathrm{~mm}^{3}$ cubes, fixed in $3 \%$ glutaraldehyde and then $1 \%$ osmium tetroxide, and dehydrated successively in ethanol and embedded in Epon 812 medium. After ultrathin $(50 \mathrm{~nm})$ sectioning and staining in uranyl acetate and lead citrate, samples were examined in an FEITecnai 12 transmission electron microscope in South China Agricultural University and the USDA-ARS San Joaquin Valley Agricultural Sciences Center in Parlier, CA.

\section{RESULTS}

The presence of phytoplasma was indicated by an expected $\approx 800$-bp DNA amplicon using specific primer set fU5/rU3 nested with primer set P1/P7 (Fig. 2). The phytoplasma is tentatively

TABLE 2. Information about primers used for polymerase chain reaction detection of 'Candidatus Liberibacter asiaticus' and phytoplasma in this study

\begin{tabular}{|c|c|c|c|c|}
\hline Primer set & Sequence $\left(5^{\prime}\right.$ to $\left.3^{\prime}\right)$ & Amplicon size (bp) & Specificity & Reference \\
\hline $\mathrm{fD} 1 / \mathrm{fD} 2$ & agagtttgat cctggctcag/aaggaggtga tccagcc & $\approx 1,500$ & Bacteria & 19 \\
\hline $\mathrm{OI} 1 / \mathrm{OI} 2 \mathrm{c}$ & gcgcgtatgc aatacgagcg gca/gectcgegac ttcgcaaccc at & 1,160 & $\begin{array}{l}\text { 'Ca. L. asiaticus' and } \\
\text { 'Ca. L. africanus' }\end{array}$ & 19 \\
\hline $\mathrm{P} 1 / \mathrm{P} 7$ & aagagtttga tcctggctca ggatt/cgtccttcat cggctctt & $\approx 1,800$ & All phytoplasmas & 9,34 \\
\hline $\mathrm{fU} 5 / \mathrm{rU} 3$ & cggcaatgga ggaaact/ttcagctact ctttgtaaca & 882 & All phytoplasmas & 29 \\
\hline HLBas/HLBp/HLBr & $\begin{array}{l}\text { tcgagcgcgt atgcaatacg/FAM-agacgggtga gtaacgcg-BHQ-1/gcgttatccc } \\
\text { gtagaaaaag gtag }\end{array}$ & 75 & 'Ca. L. asiaticus' & 25 \\
\hline
\end{tabular}


named as HLB-associated phytoplasma for the convenience of discussion. The presence of ' $\mathrm{Ca}$. L. asiaticus' was indicated by the expected $\approx 1,100$-bp DNA amplicon using specific primer set OI1/OI2c nested with primer set fD1/fD2 in the US lab (Fig. 2) and by the cycle threshold $(\mathrm{Ct})$ values smaller than 30 referenced to the values of negative controls in the China lab (data not shown). The results of PCR detection of both HLB-associated phytoplasma and ' $\mathrm{Ca}$. L. asiaticus' in the two citrus HLB surveys are presented in Table 1 . The detection rates of ' $\mathrm{Ca}$. L. asiaticus' and HLB-associated phytoplasma were slightly higher in the 2006 survey (70.4 and $78.9 \%$, respectively) than those in the 2007 survey ( 55.6 and $75.6 \%$, respectively). In both years, phytoplasma detection rates were higher than those of ' $\mathrm{Ca}$. L. asiaticus'. Among 141 HLB symptomatic samples, 110 (78.0\%) samples were phytoplasma positive. HLB-associated phytoplasma was detected in all three citrus hosts, i.e., sweet orange, pummelo, and mandarin. At the same time, $89(63.1 \%)$ samples were positive for ' $C a$. L. asiaticus'. Sixty-nine $(48.9 \%)$ samples were positive for both HLB-associated phytoplasma and ' $\mathrm{Ca}$. L. asiaticus', indicating mixed infections.

Nucleotide sequences of 18 amplicons using primer set fU5/rU3 were identical and resulted in high BLASTn matches with phytoplasma DNA sequences in GenBank database. The sequences of the $\mathrm{P} 1 / \mathrm{P} 7$ amplicons from mandarin and periwinkle were identical to each other with the length of $1,759 \mathrm{bp}$. The sequence from mandarin has been deposited in GenBank as accession number EU544303. The sequences showed $100 \%$ identity to the sequences of three strains of ' $\mathrm{Ca}$. Phytoplasma asteris' in the region of $16 \mathrm{~S}$ rDNA and $16 \mathrm{~S}-23 \mathrm{~S}$ intergenic spacer. The three phytoplasmas are onion yellows phytoplasma OY-M from Japan (AP006628, locus PAMr01), aster yellows phyto- plasma 'watercress' from Hawaii (AY665676), and valeriana yellows phytoplasma clone ValY2 from Lithuania (AY102274). The whole genome of onion yellows phytoplasma OY-M has been sequenced and contains two heterologous ribosomal RNA operons (32). While one operon (PAMr01) shared the identical sequences with EU544303 (i.e., HLB-associated phytoplasma), the sequence of the other operon (PAMr06) showed differences in two SNPs. The comparison of EU544303 to the current version of GenBank database showed that two sequences, AY734453 from barley deformation phytoplasma in Lithuania and AF222063 from aster yellows phytoplasma in United States, showed one single nucleotide polymorphism (SNP); and five sequences, AY566302 from ash witches'-broom phytoplasma in Korea, AY389820 from aster yellows phytoplasma strain AY-BW in Ohio, AY101386 from epilobium phyllody phytoplasma in Estonia, AF322644 from aster yellows phytoplasma strain AY1 clone 14 in United States and AY744070 from Silene virescence phytoplasma in United States, showed two SNPs.

All four of the graft-inoculated periwinkle plants showed leaf yellowing symptoms 1 month after grafting. As infected plants began to flower, virescence and phyllody symptoms appeared (Fig. 3A and B). Non-inoculated periwinkle did not show any symptoms (Fig. 3C). TEM revealed that many sieve tubes of infected periwinkle with virescence and phyllody symptoms were filled with pleomorphic cells enclosed by a membrane layer of $6.5 \mathrm{~nm}(n=10)$ in thickness (Fig. 3D). A clear unit membrane and distinct pleomorphic morphology (Fig. 3D) were indicative of phytoplasmas $(18,23)$. Cells with thicker border, presumably cell wall, of $27.2 \mathrm{~nm}(n=10)$ were also observed. However, they were low in titer, scattered within the sieve tubes, and often observed along with thin-bordered cells (data not shown). Similarly, both

\section{Strain name}

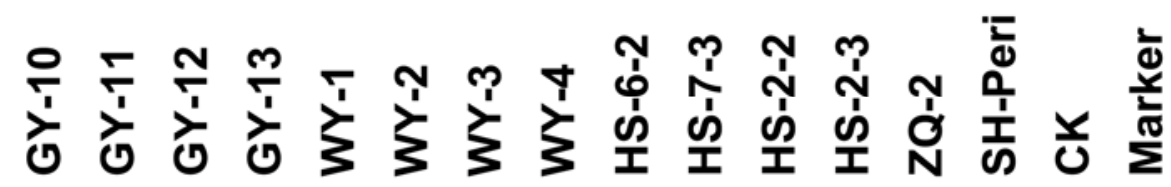

Ca. P. asteri
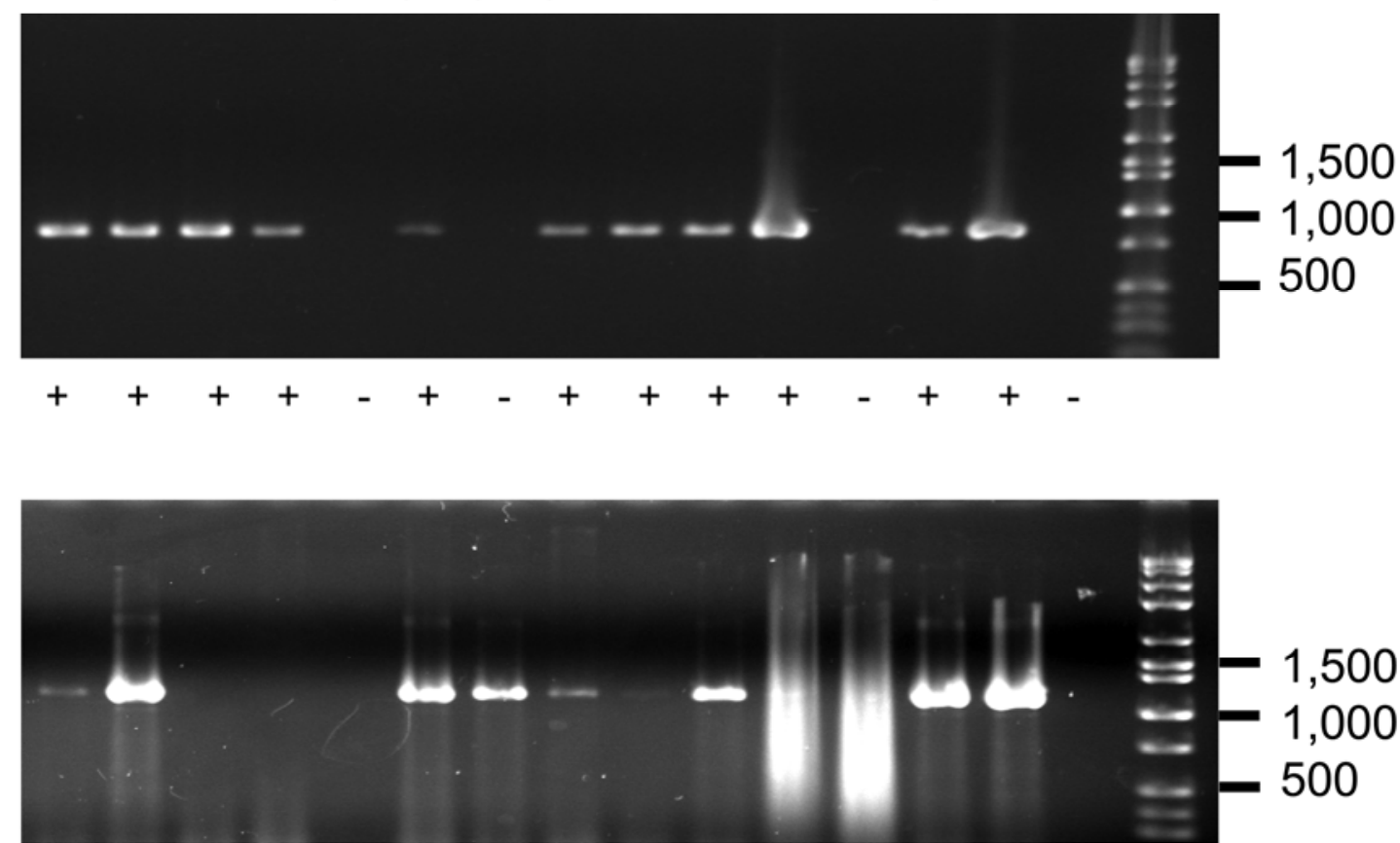

\section{Ca. L. asiaticus}

Fig. 2. Agarose gel analysis of polymerase chain reaction amplicons of huanglongbing-associated bacteria: 'Candidatus Phytoplasma asteris' (top panel) and 'Ca. Liberibacter asiaticus' (bottom panel) from 14 representative plants in Guangdong, China. GY-10, GY-11, GY-12, GY-13, HS-2-2, HS-2-3, and ZQ-2 were from mandarin; WY-1, WY-2, WY-3, WY-4, HS-6-2, and HS-7-3 were from sweet orange; SH-Peri was from periwinkle; and CK was from healthy mandarin. DNA size markers (bp) on the last lane in both panels. 
cells with a thin border $(8.0 \mathrm{~nm}, n=10)$ and a thick border (20.7 nm, $n=10$ ) were observed from HLB citrus samples, both in low titer. Pleomorphic bodies were not found in citrus samples. The thick-bordered cells suggested walled bacteria and the thin bordered cells were indicative of phytoplasma.

\section{DISCUSSION}

Currently, it is generally agreed that citrus HLB is associated with ' $C a$. Liberibacter' worldwide $(3,19)$. The presence of ' $C a$. L. asiaticus' in HLB-affected citrus trees in Guangdong has also been confirmed using DNA-based methods $(9,10,11,12,13)$. However, efforts to find ' $\mathrm{Ca}$. L. africanus' and ' $\mathrm{Ca}$. L. americanus' in China were not successful (9). In this study, DNA analyses led to the identification of a phytoplasma from HLB citrus. We were unable to identify high titers of the HLB-phytoplasma in citrus sieve tubes by TEM. However, a high titer of phytoplasma was found in periwinkle inoculated with HLB citrus, suggesting that periwinkle could be used for the enrichment of HLB-associated phytoplasma in future studies.

Identification and characterization of ' $\mathrm{Ca}$. L. asiaticus' began with the Poona strain from HLB-affected sweet orange in India $(14,19)$. Virescence and phyllody symptoms were not observed in periwinkle infected with the Poona strain (14), suggesting that phytoplasmas were not present in the donor citrus tree. In Guangdong, we detected only ' $\mathrm{Ca}$. L. asiaticus' in $14.2 \%$ of the samples. Whether phytoplasmas are present in HLB citrus in India, as well as in other citrus growing regions, remains to be determined. It is interesting to note that in this study, phytoplasma was associated more with HLB than was ' $\mathrm{Ca}$. L. asiaticus' (78.0 versus $63.1 \%$, respectively). A paired $t$ test on the infection rates of phytoplasma and ' $\mathrm{Ca}$. L. asiaticus' returned a $P$ value of 0.057 , which could be considered as marginally different at the significance level of 0.05 .

A total of $29.1 \%$ of the HLB samples were detected with phytoplasma only, evidence of phytoplasma correlated with HLB symptoms. In a separate experiment, we randomly collected and tested 10 asymptomatic mandarin leaves from non-HLB-affected trees in Guangdong. Eight were phytoplasma-negative and two were positive. We also tested 10 leaves of sweet orange collected from California. None was phytoplasma-positive. However, more data, particularly those from controlled experiments, are needed to better establish the association of phytoplasma with HLB. Studies of HLB-associated bacteria from different geographical regions have led to the identification of different putative etiological agents of HLB. DNA sequence analysis on ' $\mathrm{Ca}$. Liberibacter' strains in South Africa led to the identification of ' $\mathrm{Ca}$. $\mathrm{L}$. africanus' (14,19), and recent research from Brazil identified ' $\mathrm{Ca}$. L. americanus' (35).

In China, the highly destructive nature of HLB and the urgent need to control the disease prompted intensive efforts to search for the HLB etiological agents before the recognition of ' $\mathrm{Ca}$. L.
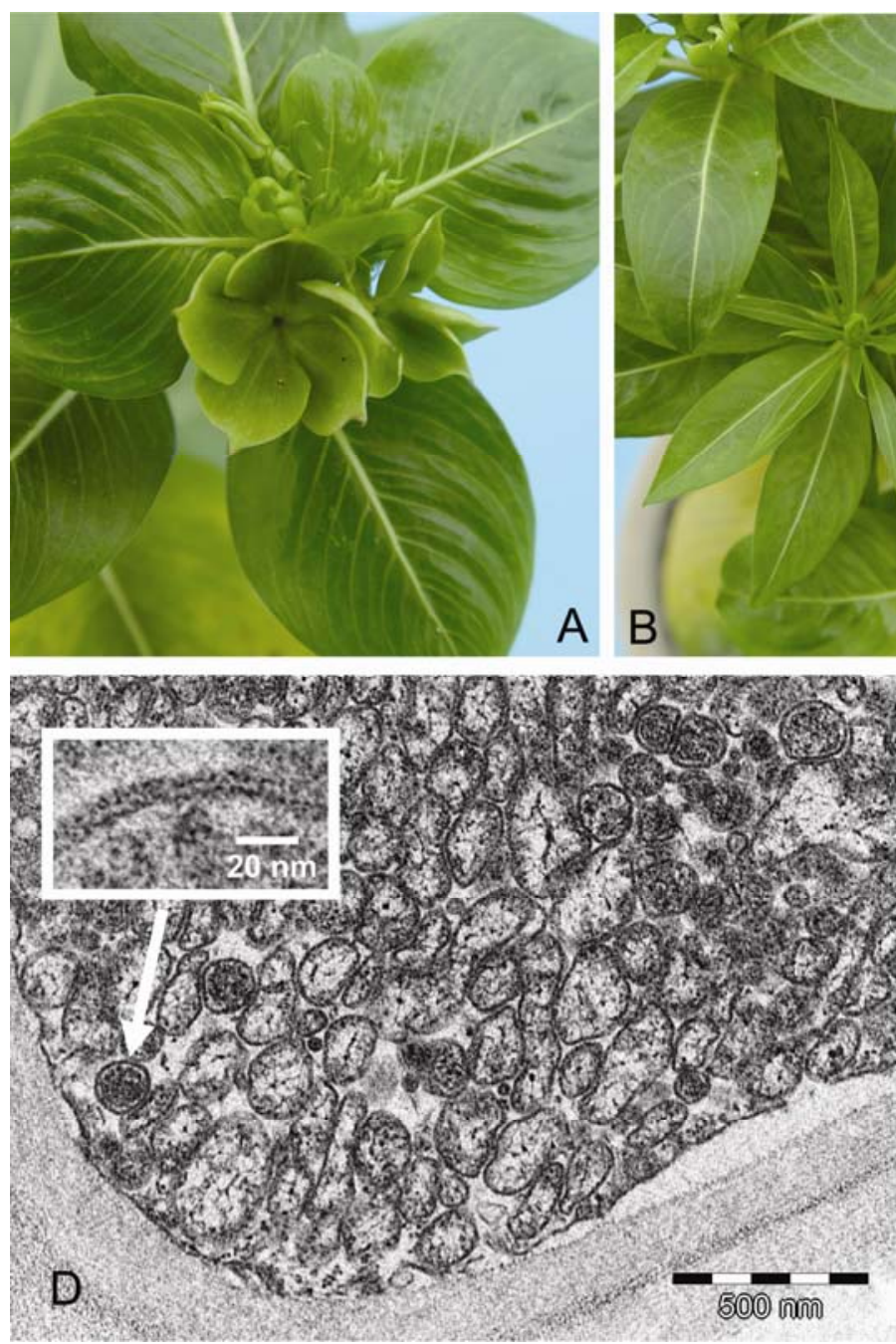
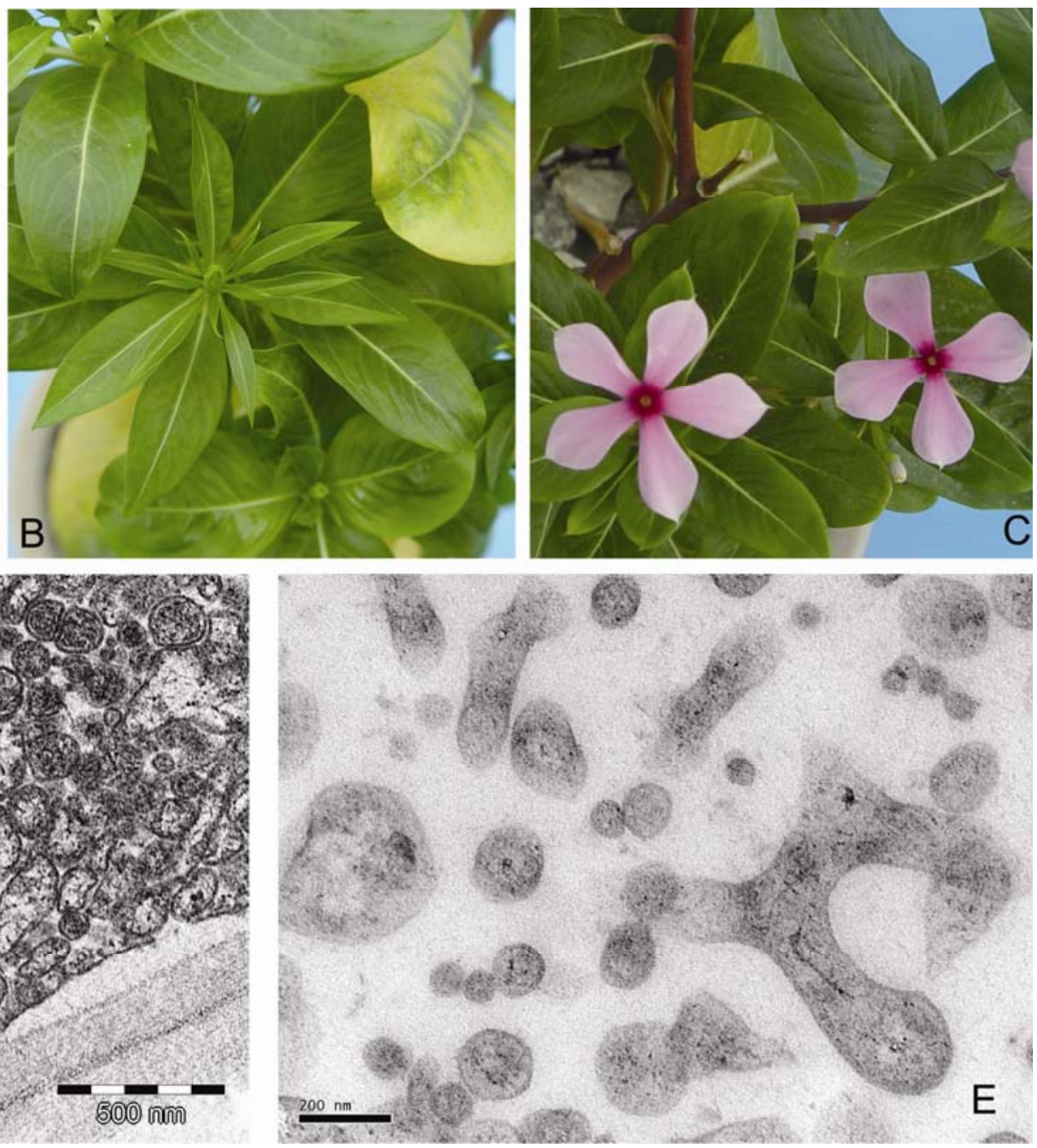

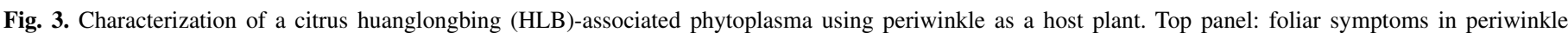

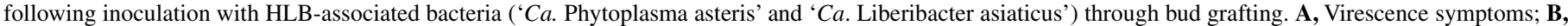

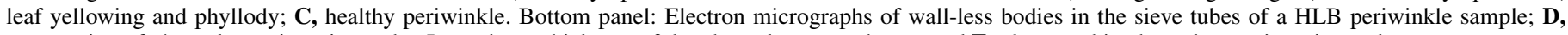
aggregation of phytoplasma in a sieve tube. Inset shows thickness of the phytoplsma membrane; and $\mathbf{E}$, pleomorphic phytoplasmas in a sieve tube. 
asiaticus' (39). MLOs/phytoplasmas and BLOs were observed in HLB-affected citrus tissue using TEM (6,21). Interestingly, although pleomorphic cells were reported and MLOs/phytoplasma was suspected in HLB-affected citrus (6), the thickness of the cell envelop as reported to be $20 \mathrm{~nm}$, similar to that of the walled bacteria observed in this study. Since the titer level was not mentioned and presumably low, we speculate that the previous confusion could be related to the presence of both walled and wall-less bacteria in HLB-affected citrus.

Based on the current taxonomic scheme (24), the HLB-associated phytoplasma from this study belongs to the Aster yellows group (16SrI-B), and therefore designated as a strain of ' $\mathrm{Ca}$. P. asteris'. The 16SrI-B group phytoplasmas are associated with more than 100 economically important diseases worldwide and represent the most diverse and widespread phytoplasma group. Analyses of $16 \mathrm{~S}$ rDNA sequences may not be sufficient to elucidate strain relationships. The biological properties of the ' $C a$. P. asteris' HLB-associated strain, such as pathogenicity, insect vector and plant host range, remain to be determined. The genome of the onion yellows phytoplasma has been sequenced (32). These could provide important information for further genome study of the phytoplasma in HLB-affected citrus.

Meanwhile, phytoplasma in the 16SrI group has never been reported from citrus. Based on our knowledge, only phytoplasmas related to $16 \mathrm{Sr}$ II group, ' $\mathrm{Ca}$. P. aurantifolia', have been identified to be associated with citrus diseases in Ethiopia (1), India (17), Iran (4), Oman (2), and the United Arab Emirates (16). As this manuscript was in submission, a phytoplasma closely related to the pigeon pea witches'-broom phytoplasma (16SrIX) was reported to be associated with citrus HLB symptoms in the State of São Paulo in Brazil (37). The phytoplasma was first identified in a new HLB area where citrus trees showed HLB symptoms but were negative for ' $C a$. L. spp.'. As sample size increased, mixed infection by both phytoplasma and ' $\mathrm{Ca}$. L. spp.' was also found. The phytoplasmas from China and Brazil are distantly related and could represent two different species. Referenced to the fact that several ' $C a$. L. spp.' were associated with HLB, it is also possible that more HLB-associated phytoplasmas could be found in the future as research on HLB continues.

In summary, we detected both phytoplasma and ' $\mathrm{Ca}$. L. asiaticus' in HLB-affected citrus in Guangdong. PCR data showed both co-infection $(48.9 \%)$ and single infection $(29.1 \%$ for phytoplasma and $14.2 \%$ for ' $\mathrm{Ca}$. L. asiaticus'). We were not able to clearly identify symptoms specifically associated with either bacterium alone or together. Interestingly, by observing two distinct symptomatologies, yellow shoot and leaf mottling, in southern China, Lin (28) proposed that HLB could be caused by two different viruses. Nevertheless, the true etiological role(s) of phytoplasma, as well as ' $C a$. L. asiaticus', in HLB remain(s) uncertain until Koch's postulates are fulfilled.

\section{ACKNOWLEDGMENTS}

We thank D. Hoffmann, R. Alvarez, and G. Phillips for their technical assistance. We also thank J. Smilanick and M. Sisterson for their statistical assistance. Part of this research was supported by Guangdong Provincial Foundation of Natural Sciences (2006025850), Special Research Programs of Plant Quarantine of Guangdong (F08037), and California Citrus Research Board (project 5210-135).

\section{LITERATURE CITED}

1. Arocha, Y., Bekele, B., Tadesse, D., and Jones, P. 2007. First report of a 16SrII group phytoplasma associated with die-back diseases of papaya and citrus in Ethiopia. Plant Pathol. 56:1039-1039.

2. Bove, J. M. 1986. Outbreaks and new records. Oman. Witches'-broom disease of lime. FAO Plant Protect. B. 34:217-218.

3. Bove, J. M. 2006. Huanglongbing: A destructive, newly-emerging, century-old disease of citrus. J. Plant Pathol. 88:7-37.
4. Bove, J. M., Danet, J. L., Bananej, K., Hassanzadeh, N., Taghizadeh, M., Salehi, M., and Garnier, M. 2000. Witches'-broom disease of lime in Iran. Pages 207-212 in: Proceedings of the 14th Conference of Int. Organ. Citrus Virol. IOCV, Riverside, US.

5. Chen, C. P. 1943. A report of a study on yellow shoot disease of citrus in Chaoshan. New Agric. J. 3:142-177.

6. Chen, T.-Y., Shen, C.-Y., Tao, S.-C., Kung, T.-H., Chen, N.-W., and Tai, Y.-M. 1979. Studies on the pathogens of Huanglongping (citrus yellow shoot disease)-III. Mycoplasma-like organisms associated with Huanglongping in Kwangtung. Acta Bioch. Bioph. Sin. 11:191-193.

7. Coletta-Filho, H. D., Takita, M. A., Targon, M. L. P. N., and Machado, M. A. 2005. Analysis of $16 \mathrm{~S}$ rDNA sequences from citrus Huanglongbing bacteria reveal a different ' $\mathrm{Ca}$. Liberibacter' strain associated with citrus disease in Sao Paulo. Plant Dis. 89:848-852.

8. Deng, S., and Hiruki, C. 1991. Amplification of 16S rRNA genes from culturable and non-culturable mollicutes. J. Microbiol. Methods 14:53-61.

9. Deng, X., Chen, J., Feng, Z., Shan, Z., Guo, H., Zhu, J., Li, H., and Civerolo, E. L. 2008. Identification and characterization of the Huanglongbing bacterium in pummelo from multiple locations in Guangdong, P. R. China. Plant Dis. 92:513-518.

10. Deng, X., Liang, Z., and Tang, W. 1999. Studies on the rapid detection of citrus Huanglongbing pathogen. J. South China Agric. Univ. 20:1-4.

11. Deng, X., and Tang, W. 1996. The studies on detection of citrus Huanglongbing pathogen by polymerase chain reaction. J. South China Agric. Univ. 17:119-120.

12. Deng, X., and Tang, W. 1998. Application of polymerase chain reaction to the detection of citrus Huanglongbing pathogen. J. Zhejiang Agric. Univ. 24:5571-5562.

13. Deng, X., Zhou, G., Li, H., Chen, J., and Civerolo, E. 2007. Detection of Candidatus Liberibacter asiaticus from Wampee (Clausena lansium Skeels) by nested PCR. Plant Health Progress doi:10.1094.

14. Garnier, M., and Bove, J. M. 1983. Transmission of the organism associated with citrus greening disease from sweet orange to periwinkle by dodder. Phytopathology 73:1358-1363.

15. Garnier, M., Jagoueix-Eveillard, S., Cronje, P. R., Le Roux, H. F., and Bove, J. M. 2000. Genomic characterization of a Liberibacter present in an ornamental rutaceous tree, Calodendrum capense, in the Western Cape Province of South Africa. Proposal of 'Candidatus Liberibacter africanus subsp. Capensis’. Int. J. Syst. Evol. Microbiol. 50:2119-2125.

16. Garnier, M., Zreik, L., and Bove, J. M. 1991. Witches'-broom, a lethal mycoplasmal disease of lime in the Sultanate of Oman and the United Arab Emirates. Plant Dis. 75:546-551.

17. Ghosh, D. K., Das, A. K., Singh, S., Singh, S. J., and Ahlawat, Y. A. 1999. Occurrence of witches'-broom, a new phytoplasma disease of acid lime (Citrus aurantifolia) in India. Plant Dis. 83:302.

18. IRPCM Phytoplasma/Spiroplasma Working Team-Phytoplasma Taxonomy Group. 2004. 'Candidatus Phytoplasma', a taxon for the wall-less, non-helical prokaryotes that colonize plant phloem and insects. Int. J. Syst. Evol. Microbiol. 54:1243-55.

19. Jagoueix, S., Bove, J. M., and Garnier, M. 1994. The phloem-limited bacterium of greening disease of citrus is a member of the alpha subdivision of the Proteobacteria. Int. J. Syst. Bacteriol. 44:379-386.

20. Jagoueix, S., Bove, J. M., and Garnier, M. 1996. PCR detection of the two 'Candidatus' Liberobacter species associated with greening disease of citrus. Mol. Cell. Probes 10:43-50.

21. Ke, C., Lin, X. J., Chen, H., Chen, Y. C., and Chang, L. J. 1979. Preliminary study on the relation between a rickettsia-like organism and a filamentous virus to citrus yellow shoot disease. Chinese Sci. Bull. 10:463-466.

22. Lee, I.-M., Davis, R. E., and Fletcher, J. 2001. Cell-wall free bacteria. Page 283-320 in: Laboratory Guide for Identification of Plant Pathogenic Bacteria. 3rd ed. N. W. Schaad, J. B. Jones, and W. Chun, eds. American Phytopathological Society, St. Paul, MN.

23. Lee, I.-M., Davis, R. E., and Gundersen-Rindal, D. E. 2000. Phytoplasma: Phytopathogenic mollicutes. Annu. Rev. Microbiol. 54:221-255.

24. Lee I.-M., Gundersen-Rindal, D. E., Davis, R. E., Bottner, K. D., Marcone, C., and Seemüller, E. 2004. 'Candidatus Phytoplasma asteris', a novel phytoplasma taxon associated with aster yellows and related diseases. Int. J. Syst. Evol. Microbiol. 54:1037-1048.

25. Li, W., Hartung, J. S., and Levy, L. 2006. Quantitative real-time PCR for detection and identification of Candidatus Liberibacter species associated with citrus huanglongbing. J. Microbiol. Methods 66:104-15.

26. Lin, K.-H. 1956. Observations on yellow shoot of citrus. Acta Phytopathol. Sin. 2:1-11.

27. Lin, K.-H. 1956. Etiological studies of yellow shoot of citrus. Acta Phytopathol. Sin. 2: 13-42.

28. Lin, K.-H. 1977. A discussion on citrus Huanglongbing. South China Fruits 1977:28-38.

29. Lorenz, K.-H., Schneider, B., Ahrens, U., and Seemuller, E. 1995. Detection of the apple proliferation and pear decline phytoplasmas by PCR 
amplification of ribosomal and nonribosomal DNA. Phytopathology 85:771-776.

30. Murray, M. G., and Thompson, W. F. 1980. Rapid isolation of high molecular weight plant DNA. Nucleic Acids Res. 8:4321-4324.

31. Murray, R. G. E., and Stackebrandt, E. 1995. Taxonomic Note: Implementation of the provisional status Candidatus for incompletely described procaryotes. Int. J. Syst. Bacteriol. 45:186-187.

32. Oshima, K., Kakizawa, S., Nishigawa, H., Jung, H. Y., Wei, W., Suzuki, S., Arashida, R., Nakata, D., Miyata, S., Ugaki, M., and Namba, S. 2004. Reductive evolution suggested from the complete genome sequence of a plant-pathogenic phytoplasma. Nat. Genet. 36:27-29.

33. Scora, R. W., and Nicolson, D. H. 1986. The correct name for the Shaddock, Citrus maxima, not $C$. grandis (Rutaceae). Taxon 35:592-595.

34. Smart, C. D., Schneider, B., Blomquist, C. L., Guerra, L. J., Harrison, N. A., Ahrens, U., Lorenz, K. H., Seemüller, E., and Kirkpatrick, B. C. 1996. Phytoplasma-specific PCR primers based on sequences of the 16S-23S rRNA spacer region. Appl. Environ. Microbiol. 62:2988-2993.
35. Tang, W., and Faan, H.-C. 1987. An investigation on Vinca rosea as a host plant of citrus yellow shoot BLO. J. South China Agric. Univ. 8:15-19.

36. Teixeira, D. C., Saillard, C., Eveillard, S., Danet, J. L., da Costa, P. I., Ayres, A. J., and Bove, J. 2005. 'Candidatus Liberibacter americanus', associated with citrus huanglongbing (greening disease) in Sao Paulo State, Brazil. Int. J. Syst. Evol. Micr. 55:1857-1862.

37. Teixeira, D. C., Wulff, N. A., Martins, E. C., Kitajima, E. W., Bassanezi, R., Ayres, A. J., Eveillard, S., Saillard, C., and Bové, J. M. 2008. A phytoplasma closely related to the pigeon pea witches'-broom phytoplasma (16Sr IX) is associated with citrus huanglongbing symptoms in the State of São Paulo, Brazil. Phytopathology 98:977-984.

38. Thompson, J. D., Higgins, D. G., and Gibson, T. J. 1994. CLUSTAL W: Improving the sensitivity of progressive multiple sequence alignment through sequence weighting, position-specific gap penalties and weight matrix choice. Nucleic Acids Res. 22:4673-4680.

39. Zhao, X. Y. 1981. Citrus yellow shoot disease (Huanglongbing) in ChinaA review. Proc. Int. Soc. Citriculture 1:466-469.

\section{Erratum}

The bacterial name 'Candidatus Phytoplasma asteri' was corrected to 'Candidatus Phytoplasma asteris' throughout this article. Changes to this article were made on January 18, 2010. 